\title{
A angústia diante da morte em "Lázaro", de Hilda Hilst \\ Willian André
}

Tendo dito isso, gritou em alta voz: "Lázaro, vem para fora!" O morto saiu, com os pés e mãos enfaixados e com o rosto recoberto com um sudário. Jesus lhe disse: "Desatai-o e deixai-o ir".

João, 11: 43-44

só falta que Jesus, olhando o corpo abandonado pela alma, estenda para ele os braços como o caminho por onde ele há-de regressar, e diga, Lázaro, levanta-te, e Lázaro levantar-se-á porque Deus o quis, mas é neste instante, em verdade último e derradeiro, que Maria de Magdala põe uma mão no ombro de Jesus e diz, Ninguém na vida teve tantos pecados que mereça morrer duas vezes.

José Saramago

A ressurreição de Lázaro, narrada no $11^{\circ}$ capítulo do Evangelho de João, é uma das mais célebres passagens do Novo Testamento. Entre os vários milagres perpetrados por Cristo ao longo de sua preparação para o Calvário, poderíamos considerá-la, de certa forma, o mais "ousado", uma vez que implica, conforme a interpretação teológica, na vitória do homem sobre a morte - ainda que por intervenção sobre-humana. O breve estudo que ora iniciamos tem por objetivo refletir justamente sobre a impossibilidade de se concretizar essa vitória desenhada sob a pena do quarto evangelista, tomando como ponto de partida uma releitura do referido episódio: a narrativa "Lázaro", de Hilda Hilst.

Publicado originalmente em Fluxo-Floema (1970), primeira obra em prosa da autora, o texto em questão nos apresenta a ressurreição de Lázaro narrada sob um ponto de vista bastante particular: o do próprio ressuscitado. Logo em suas primeiras linhas, percebemos que Lázaro está morto, e que sua narrativa é construída a partir de uma espécie de "estado de pós-morte". "O meu corpo enfaixado" são as primeiras palavras do personagem, que prossegue relatando como sua irmã, Marta, cuidou de seu corpo:

${ }^{1}$ Doutorando em estudos literários e professor da Universidade Estadual do Paraná (UNESPAR), Campo Mourão, PR, Brasil. E-mail: willianandreh@ hotmail.com 
Primeiro ela tirou minha roupa. E tirar a roupa de um morto é colocar outra. Depois lavou-me. Depois escolheu as essências. São todas muito dispendiosas, mas eu fui encharcado de essências. Não, ela não me tirou as vísceras, não pensem nisso, não é isso que eu quero dizer. Ela embebeu as faixas nas essências. É isso que eu quero dizer. E depois ela enfaixou-me, os gestos amplos, pausados, indubitáveis, indubitáveis sim, o gesto de quem está fiando. Fiando numa roca sem tempo. Observei-a desde o início... esperem um pouco, como é que se pode explicar esse tipo de coisa... estou pensando... acho que é melhor dizer assim: observeia, logo depois de passar por essa coisa que chamam de morte (Hilst, 2003, p. 111-112).

Após narrar os cuidados tomados pela irmã na preparação de seu corpo para o funeral, Lázaro retrocede no tempo, para descrever o que sentiu no exato momento em que morria:

Primeiro um golpe seco na altura do coração. O espanto de sentir esse golpe. Os olhos se abrem, a cabeça vira para o lado, tenta erguer-se, e dá tempo de perceber um prato de tâmaras na mesa comprida da outra sala. Dá tempo de pensar: alguém que não eu vai comer essas tâmaras. A cabeça vira para o outro lado. A cabeça ergue-se. A janela está aberta. E vejo as figueiras, vejo as oliveiras. Foi assim mesmo: vi tâmaras, figueiras, oliveiras. De repente vejo Marta. Ela põe as duas mãos sobre a boca. Ainda tento dizer: Marta, Marta, pare de arrumar a casa, eu estou morrendo. Tento dizer, mas uma bola quente vem subindo pela garganta, agora está na minha boca, tento dizer: Marta, Marta, é agora. Ainda vejo a cabeça de Maria na beira da cama. A cabeça cheia de cabelos escuros na beira da cama. Foi a última coisa que vi: a cabeça de Maria (Hilst, 2003, p. 112).

Nosso narrador-protagonista, portanto, é um defunto. E, assim como o Lázaro da Bíblia, ele será ressuscitado. Mas ao contrário da ideia de negação/superação da morte evidenciada na narrativa do evangelista João, o Lázaro de Hilst, mesmo depois de ressuscitado, carrega consigo a consciência pungente de uma morte que não pode ser evitada/superada. Por essa razão, parece-nos adequado para pensar a condição do personagem o conceito heideggeriano de ser para a morte. Segundo a perspectiva aqui adotada, o Lázaro de Hilst, como se trouxesse entranhado 
na pele um odor de morte que perfume algum é capaz de lavar, pode ser entendido como uma espécie de "ser para a morte encarnado".

Para verificar a validade dessa interpretação, devemos recuperar algumas reflexões propostas pelo autor alemão em Ser e Tempo: "A morte", diz Heidegger, "é uma possibilidade-de-ser que o Dasein tem de assumir cada vez ele mesmo. Com a morte o Dasein é iminente ele mesmo para ele mesmo em seu poder-ser mais-próprio" (Heidegger, 2012, p. 691, grifo do autor). Em outras palavras, o aflorar de uma consciência sobre a finitude (do saber-se mortal) configura-se como a possibilidade mais própria do Dasein, justamente por representar "a possibilidade do já-não-poder-ser'aí'": "Nessa possibilidade está em jogo para o Dasein pura e simplesmente o seu ser-no-mundo. Sua morte é a possibilidade do já-nãopoder-ser-'aí'" (Heidegger, 2012, p. 691). Por conta dessa condição de poder-ser mais próprio, sob a perspectiva do ser para a morte, esta (a morte) deve ser compreendida como sua "possibilidade mais-própria, irremetente e insuperável" (Heidegger, 2012, p. 691).

Corroborando essa perspectiva, Françoise Dastur observa: "podemos afirmar que a humanidade não alcança a consciência de si mesma a não ser através do enfrentamento da morte" (Dastur, 2002, p. 13). A consciência adquirida a partir do enfrentamento da morte de que fala a autora é uma maneira de se pensar a morte como possibilidade mais própria do Dasein. A mesma reflexão transparece, ainda, na interpretação do ser para a morte feita por Mario Perniola:

O ser-para-a-morte é antecipação (Vorlaufen) da morte: ser-aí (Dasein) significa para Heidegger "ser-para-o-fim". A morte não é uma simples-presença que ainda não se tornou realidade, mas uma iminência sobranceira que constitui existencialmente o ser-aí. Ela é o ser-possível mais próprio do ser-aí, irrestrita, insuperável, certa, indeterminada (Perniola, 2000, p. 168, grifos do autor).

Conforme as reflexões de Heidegger, a afirmação dessa consciência da morte se opõe ao caráter de distanciamento normalmente construído pelo cotidiano, que pretende torná-la impessoal. Segundo o autor, o discurso do modo do ser para a morte cotidiano é entendido "como algo indeterminado que deve vir alguma vez de alguma parte, mas que de imediato ainda não é subsistente para a-gente, não importando, por conseguinte, em nenhuma ameaça" (Heidegger, 2012, p. 697, grifo do autor). Nos termos da leitura aqui pretendida, essa tentativa de produzir um efeito de impessoalidade pode ser vislumbrada na concepção cristã 
de negação/superação da morte concretizada pela ressurreição de Lázaro. $\mathrm{Na}$ narrativa original do episódio, pouco antes de realizar o milagre, Cristo dirige-se a Deus, proferindo as seguintes palavras (João 11: 41-42): "Pai, dou-te graças porque me ouviste./ Eu sabia que sempre me ouves;/ mas digo isso por causa da multidão/ que me rodeia,/ para que creiam que me enviaste" (Evangelho Segundo São João, 2012: 1873). Tais versos expressam a confiança em um Deus em cujo regaço a morte deixa de constituir uma ameaça. Em outras palavras, mantendo o diálogo com Heidegger, constitui-se aí um sufocamento daquela que deveria ser a possibilidade mais própria e insuperável do Dasein.

Percorrendo o caminho contrário, a narrativa de Hilst aqui analisada propõe uma afirmação do enfrentamento da morte em detrimento da impessoalidade do cotidiano. Antes de verificarmos, todavia, de que forma o ser para a morte é encarnado na figura do protagonista da narrativa, devemos refletir sobre a relação de extrema proximidade que se constrói, para Heidegger, entre a morte e o conceito de angústia pois é o aflorar da angústia em "Lázaro" que nos permitirá construir o diálogo aqui pretendido. O autor de Ser e Tempo reflete:

A dejecção na morte se lhe desvenda do modo mais originário e mais penetrante no encontrar-se da angústia. A angústia diante da morte é a angústia "diante" do mais-próprio, irremetente e insuperável poder-ser. O diante de quê dessa angústia é o ser-nomundo ele mesmo. O porquê dessa angústia é pura e simplesmente o poder-ser do Dasein (Heidegger, 2012, p. 693).

O ser para a morte, portanto, é um ser em angústia. O angustiar-se é condição para que se configure a consciência do saber-se mortal, e se atinja, assim, a possibilidade de existência mais autêntica que o Dasein pode assumir. No contexto da filosofia moderna, o autor dinamarquês Sören Kierkegaard foi um dos primeiros a discorrer sobre o conceito de angústia. Para Kierkegaard, o desabrochar desse estranhamento surge a partir do deparar-se com um vazio primordial, uma ausência de objeto que não se pode preencher. Em $O$ conceito de angústia, o autor pondera que esta estabelece laços com o enfrentamento do indivíduo com o nada: “Aí está o mistério profundo da vida: é, ao mesmo tempo, angústia. Sonhador, o espírito projeta a sua própria realidade, que é um átimo, e a inocência vê sempre e sempre, diante de si, esse nada" (Kierkegaard, 2007, p. 50). E mais adiante: "Perguntando mais de perto qual é a finalidade da angústia, deve retrucar-se, neste ponto como 
sempre, que é um nada. A angústia e o nada jamais deixam de se equivaler" (Kierkegaard, 2007, p. 112). Uma imagem recorrente em sua obra é a do homem diante do abismo:

A angústia pode ser comparada à vertigem. Quando o olhar imerge em um abismo, existe uma vertigem que nos chega tanto do olhar como do abismo, visto que nos seria impossível deixar de o encarar. Esta é a angústia, vertigem da liberdade, que surge quando, ao desejar o espírito estabelecer a síntese, a liberdade imerge o olhar no abismo das suas possibilidades e agarra-se à finitude para não soçobrar (Kierkegaard, 2007, p. 74).

A imagem do abismo está associada a uma ideia de vazio, ausência, falta. Se pensarmos no termo correspondente em alemão, Ab-grund, perceberemos que, além de uma falta $(A b)$ física de "chão", "solo" (Grund), a palavra também remete à falta de razão, sentido, causa (significados que também se inscrevem na palavra Grund). Portanto, trata-se de uma maneira de se pensar a representação do nada, e é em face desse nada, segundo Kierkegaard, que se constituirá a angústia. Converge para aquilo que aqui pretendemos significar a imagem empregada por Clément Rosset em "L'angoisse": a imagem do mundo mudo, que se apresenta ao homem de forma bruta, inescrutável, fechado em um silêncio que não permite qualquer possibilidade de se construir significados satisfatórios e permanentes: "Preso em si mesmo, tal como se apresenta na intuição do doar-se, o mundo é mudo. O silêncio do mundo é provavelmente a fonte principal da angústia diante da doação da qual derivam as construções morais" (Rosset, 2000, p. 47, tradução nossa). Devemos lembrar, ainda, que também Heidegger sugere uma aproximação entre angústia e nada. ${ }^{2}$ Em "Que é metafísica?", o autor reflete:

"Estamos suspensos" na angústia. Melhor dito: a angústia nos suspende porque ela põe em fuga o ente em sua totalidade. Nisto consiste o fato de nós próprios - os homens que somos refugiarmo-nos no seio dos entes. É por isso que, em última análise, não sou "eu" ou não és "tu" que te sentes estranho, mas a gente se sente assim. Somente continua presente o puro ser-aí no estremecimento deste estar suspenso onde nada há em que apoiar-se (Heidegger, 1979, p. 39).

${ }^{2}$ Conforme aponta Roger Poole (2009, p. 51-54), muitas das reflexões do autor alemão são tributárias da obra de Kierkegaard. 
Em “Lázaro", é o aflorar da angústia que nos permite construir uma associação entre a figura de seu narrador-protagonista e o conceito de ser para a morte. Para compreender como essa angústia que se instala em face do nada é configurada no texto de Hilst, devemos ter em mente as diversas passagens da narrativa em que Lázaro é confrontado ora com uma falta primordial, ora com uma vastidão opressora. A oscilação entre esses dois extremos remete às reflexões de Edmund Burke acerca do conceito de sublime, desenvolvidas na obra Uma investigação filosófica sobre a origem de nossas idéias do sublime e do belo, também importante para a leitura aqui proposta, à medida que trata da morte, permitindonos vislumbrar como, em razão desta, surge a angústia.

Não nos interessa aqui considerar a obra de Burke como um todo, mas sim o momento específico em que ele discorre sobre a importância da morte para o desenvolvimento de suas investigações. Segundo o autor, o conceito de sublime - tudo aquilo que "produz a mais forte emoção de que o espírito é capaz" (Burke, 1993, p. 48) -, em oposição ao belo, está atrelado a um conjunto de emoções de aspecto negativo, como dor, perigo e medo: "Tudo que seja de algum modo capaz de incitar as idéias de dor e de perigo, isto é, tudo que seja de alguma maneira terrível ou relacionada a objetos terríveis ou atua de um modo análogo ao terror constitui uma fonte do sublime" (Burke, 1993, p. 48, grifo do autor). Como centro dessa série de emoções que podem provocar o sublime, o autor elege a morte, por ele considerada "a rainha dos terrores":

Não obstante o efeito da dor seja muito mais forte do que o do prazer, ela geralmente causa uma impressão muito menor do que a idéia de morte, dado que dificilmente a esta se prefere, até mesmo em lugar das dores mais extremas; ademais, o que geralmente torna a própria dor, se me é lícito dizê-lo, mais dolorosa é ser considerada a emissária dessa rainha dos terrores (Burke, 1993, p. 48).

Ao constituir uma leitura dessas reflexões de Burke, Márcio Seligmann-Silva observa que a manifestação da morte como centro da teoria do sublime poderá assumir duas formas distintas:

O sublime, portanto, é o real enquanto manifestação da morte, ele "nos arrebata com uma força irresistível" e impede a nossa mente de raciocinar (Burke 1993: 65). Esse "sublime da morte" que aponta para uma realidade-como-morte se manifesta tanto sob a figura da privação extrema, ou seja, do real como falta primordial - como no caso das trevas, do vazio, da solidão e do silêncio 
(Burke 1993: 76) - como também sob a figura da vastidão que nos oprime e amedronta ao revelar nossa insignificância (SeligmannSilva, 2005, p. 34, grifos do autor). ${ }^{3}$

A partir deste excerto, podemos construir relações com algumas das reflexões propostas até o momento: i) o "real enquanto manifestação da morte" a que se refere o autor, mais adiante chamado por ele de realidadecomo-morte, parece possuir um teor semelhante àquele que envolve o ser para a morte heideggeriano, enquanto consciência/enfrentamento da finitude; e ii) a afirmação de que tal realidade-como-morte pode se manifestar em face de uma falta primordial (vazio, solidão, silêncio) aproxima-se da ideia de que a angústia se constitui a partir do confronto com o nada, conforme vimos nas reflexões de Kierkegaard, Rosset, e também do próprio Heidegger. Além disso, como já observamos, é a oposição "falta primordial x vastidão opressora" que orienta nossa leitura sobre a manifestação da angústia em "Lázaro". Voltemos, pois, à narrativa, para verificar de que forma essa oposição é costurada em seu desenvolvimento.

Logo após relatar o que sentiu no momento em que morria, Lázaro descreve de que forma o mundo se apresenta diante de seus olhos de morto - "Vejo de cima, dos lados, de frente, vejo de um jeito que nunca vi. Jeito de ver de um morto" (Hilst, 2003, p. 113) - e, na sequência, recupera uma memória de seu passado, de quando estava ainda vivo, e ficou a observar Jesus, sem que lhe fosse possível, todavia, descrever o que via:

Foi aqui na minha aldeia, depois das grandes chuvas. $\mathrm{O}$ ar fica duma transparência azulada, tudo se cobre, ou melhor, se descobre, é assim como se você pegasse a pele de uma gazela e a distendesse lentamente até... até ver o que eu vi dum jeito de morto: Ele estava parado. Ele pousava. Eu também estava parado, mas havia uma enorme diferença entre a minha maneira de estar parado e a maneira DELE. Ao redor de mim, esse ar que descrevi, transparência azulada. Ao redor DELE... ao redor DELE, um espaço indescritível, perdoem-me, na morte seria preciso encontrar as palavras exatas, porque na morte vê-se em profundidade, mas ainda assim não sei de uma palavra que qualifique o espaço que vi em vida ao redor DELE (Hilst, 2003, p. 113).

\footnotetext{
${ }^{3}$ A edição da obra de Burke de que se vale Seligmann-Silva para fazer suas citações é a mesma aqui utilizada.
} 
O trecho permite-nos já um primeiro vislumbre da angústia do personagem. Suas palavras denotam que ele é capaz de ver algo, mas que não encontra palavras para descrevê-lo. Sua linguagem se demonstra insuficiente para captar ou definir aquilo que paira diante de seus olhos e, se a linguagem falha, já não é possível construir sentido: Lázaro se encontra diante do indizível. A princípio, ele reflete que "tudo se cobre", como se pretendendo significar que, por ser incapaz de traduzir em palavras o que está vendo, há aí um sentido "oculto", "coberto". Na sequência, todavia, ele diz que tudo se está a descobrir, e não a se cobrir. Fica-nos a impressão de ser justamente por conta dessa espécie de desvelamento - como se o mundo repentinamente se revelasse em sua condição bruta, em um silêncio aterrador, para lembrar a imagem empregada por Rosset - que as possibilidades de construir um significado satisfatório lhe são vetadas, dando origem à angústia. A descoberta desse inominável diante de uma linguagem que se mostra limitada é evidenciada pela tentativa do personagem de tocar aquilo que lhe foge à compreensão: “Dei alguns passos apressados na direção daquele corpo. [...] Estendi o braço para tocá-lo, mas a minha mão feriuse no tronco da figueira. Não era ali que Ele estava? Ele não estava parado junto ao tronco da figueira?" (Hilst, 2003, p. 114).

Se é possível, portanto, a partir dessa interpretação, entender a angústia de Lázaro em face de uma falta, o oposto ocorre logo em seguida, quando o personagem passa a refletir sobre a presença de Deus em Cristo: "Ele é alguém feito de mim mesmo e de um Outro. O Outro, eu não lhes saberia dizer o nome. O Outro não tem nome. Talvez tenha, mas é impossível pronunciá-LO" (Hilst, 2003, p. 114). Ao observar que Cristo "é alguém feito de mim mesmo", Lázaro quer dizer que Jesus, assim como ele, é homem/humano. Mas além dessa faceta humana, há também em Cristo o divino: "um Outro", cujo nome lhe é impossível pronunciar. Em suas reflexões sobre o estudo de Burke acerca do sublime, SeligmannSilva ressalta que "A manifestação máxima do sublime enquanto infinito e poder que nos domina por inteiro é a própria idéia de Deus, que nos anula, ou ainda, nos cega" (Seligmann-Silva, 2005, p. 34). Mais uma vez, portanto, a linguagem de Lázaro se demonstra limitada, desta feita por ser incapaz de dar nome a um Deus que se faz inominável, por conta da vastidão sufocante, esmagadora, nele contida.

Na sequência da narrativa, o personagem menciona a terceira pessoa da trindade - o Espírito Santo -, para completar sua visão do todo 
compreendido na figura de Cristo, conforme a interpretação teológica: "além de mim mesmo e do Outro, há no Homem mais alguém. Esse alguém chama-se Rouah" (Hilst, 2003, p. 115). Em nenhum momento, o narrador utiliza a expressão "Espírito Santo". Todavia, o termo hebraico ruah designa, em várias passagens da Bíblia, o Espírito de Deus, o que torna bastante plausível a interpretação do Rouah hilstiano como sendo o Espírito Santo. Nesses termos, conforme as palavras de Lázaro, além dele mesmo (o humano) e do Outro (Deus), há no Homem (Jesus) mais alguém (Rouah, o Espírito Santo). Algumas linhas abaixo, o personagem refere-se a Cristo da seguinte forma: "Aquele Homem Jesus, Aquele Homem Eu Mesmo, Aquele Homem o Outro, Aquele Homem Rouah" (Hilst, 2003, p. 115).

Após essas reflexões sobre a trindade, Lázaro relata seu sepultamento. Depois de descrever o local em que seu corpo deverá permanecer, suas palavras demonstram que ele assiste à cena do sepultamento como se estivesse fora do próprio corpo, pairando acima dele: “O meu corpo foi depositado no seu lugar. Estou acima dele, a uma pequena distância. Pairo sobre ele. Os meus amigos recuam. Olham-me em silêncio" (Hilst, 2003, p. 116). E na sequência: "Inútil tentar qualquer gesto. Não me vêem. Grito três vezes: Marta! Marta! Marta! Não me ouve. Rolam a pedra. Fecham a entrada. Tudo está terminado" (Hilst, 2003, p. 116). As últimas palavras do excerto, "tudo está terminado", reforçam a ideia de fim irrevogável expressa pela morte. Mas é justamente no momento em que, aos olhos do personagem, tudo parece estar terminado, que tem início uma série de acontecimentos insólitos. O primeiro desses acontecimentos é a constatação de que Lázaro não se encontra sozinho em sua sepultura:

E de repente vejo Rouah: tosco, os olhos acesos, o andar vacilante, as pernas curtas, parecia cego, apesar dos olhos acesos, as mãos compridas, afiladas, glabras, eram absurdas aquelas mãos naquele corpo, todo ele era absurdo, inexistente, nauseante. Rouah me vê. Agarro-me na pedra. Estou num canto. De costas. Rouah estende as mãos e acaricia as minhas nádegas. Sai, maldito, sai. Rouah sentase. Abre as pernas. O seu sexo é peludo e volumoso. Coça-se, estrebucha, sem que eu saiba por quê (Hilst, 2003, p. 116-117).

Como observamos há pouco, Rouah é o Espírito Santo. E ao Espírito Santo - mantendo o diálogo até aqui travado com uma concepção teológica -, inevitavelmente associaremos, a priori, uma ideia de 
transcendência. A descrição de Rouah no texto de Hilst, todavia, é um deboche dessa suposta transcendência: o Espírito Santo que se encontra diante de Lázaro tem a aparência de um animal asqueroso. A partir dessa constatação, nossas reflexões podem se desdobrar em dois sentidos. Em primeiro lugar, se a ideia divina de transcendência contida na concepção original do Espírito Santo representa uma possibilidade de superação da morte, a releitura aqui apresentada parece percorrer o caminho inverso. Afinal, se em lugar de uma figura repleta de luz, resplandecente, a narrativa nos apresenta um Rouah tosco, com um sexo peludo e volumoso, a suposta impressão de superação da morte que ele deveria transmitir dá lugar à afirmação de uma morte que se faz insuperável. Retomando as reflexões de Heidegger, se no primeiro caso poderíamos construir uma associação com a ideia de impessoalidade e distanciamento da morte contida no discurso cotidiano, a inversão promovida por Hilst sugere a ideia de aproximação, de enfrentamento, que é condição para a configuração do ser para a morte.

Em segundo lugar, podemos dizer que a figura de Rouah constitui um paradoxo no que se refere à oposição "falta primordial $x$ vastidão opressora": se a ideia de transcendência, proveniente do fato de ser ele o Espírito Santo, remete ao segundo termo da oposição, a descrição de seus olhos acesos e andar vacilante transforma em falta qualquer possibilidade de infinitude que sua figura deveria conter. Em outras palavras, Lázaro se encontra, a um só tempo, angustiado diante da vastidão opressora que representa a ideia do Espírito Santo, e da falta suprema provocada pela corporificação desse ser "transcendente": um animal "absurdo, inexistente, nauseante". Esta impressão de angústia diante do vazio é reforçada conforme a narrativa se desenvolve:

Um enorme silêncio. Um silêncio feito do escuro das vísceras. Um silêncio de dentro do olho. Resolvo caminhar colado à pedra, afastarme. Caminhar para onde? Sou rápido: nessa reentrância oposta à presença do maldito. Três passos laterais, curvos, e estamos separados. Mas frente a frente. As minhas costas ajeitam-se no buraco da pedra. Os meus joelhos comprimem o estômago, abraçoos, mas eles têm movimento autônomo, um abrir-se e um fechar-se descontínuos. O meu esforço para detê-los é visível, e isso parece divertir Rouah: ele abre e fecha as pernas, torce o tronco várias vezes, tem incrível mobilidade - é preciso admitir - e como se adivinhasse a minha surpresa, resolve fazer demonstrações do seu talento elástico: coloca os dois pés escuros sobre a cabeça. Vejo nitidamente que os 
pés de Rouah são pés minúsculos, talvez por isso ele tem o andar vacilante. Ele abre a boca, a boca vazia e amarela, fica de pé num salto, olha ao redor, depois deita-se e começa a lamber-se. Uma língua achatada e lenta (Hilst, 2003, p. 117).

O excerto continua a descrição de um Rouah (suposto representante da transcendência divina) bizarro. Além disso, suas primeiras linhas descrevem o silêncio que paira na sepultura: "um silêncio feito do escuro das vísceras". O silêncio, conforme nossa leitura, é uma maneira de se pensar o vazio, a falta, o nada. E o nada possui estreita relação com a angústia. Encurralado nas pedras, diante de Rouah, Lázaro parece experimentar essa falta primordial, essa mudez ultrajante, esse vazio bruto que impossibilita qualquer produção de sentido. Lázaro é o homem diante do abismo, e sua suposta experiência transcendental, que deveria provocar um distanciamento da morte, só faz torná-lo mais próximo e consciente dela. O Espírito Santo hilstiano faz malabarismos e lambe o corpo peludo, evidenciando um processo de animalização. Tal impressão é reforçada algumas linhas adiante: "sinto o cheiro da minha própria carne, um cheiro viscoso, preto e marrom. Rouah também o sente, porque parou de lamber-se, levantou a cabeça, e os buracos de seu focinho se distendem, se comprimem" (Hilst, 2003, p. 118).

Em seguida, tem lugar a segunda experiência insólita vivenciada por Lázaro: Rouah faz surgir em suas mãos algo que aos poucos toma a forma de uma flor gigantesca, que é introduzida pela besta no ventre do protagonista: “Agora sim, ele está contente. Está contente como... como se acabasse de parir. É isso. A flor gigantesca afunda-se no meu ventre, a rosácea escura absorve o conteúdo das minhas vísceras" (Hilst, 2003, p. 119). Depois, novo objeto é moldado pelo ser de mãos glabras: "Rouah construiu um cálice de carne. Vejo com nitidez. Mergulha-o lentamente no meu peito" (Hilst, 2003, p. 119). As palavras do narrador dão a entender que ele está sendo fecundado por Rouah: "O meu todo que vê e sofre de maneira atroz, tenta repelir o segundo filho de Rouah. Tenta expulsá-lo. Meu peito se alarga, minha boca disforme suga uma seiva que não vê" (Hilst, 2003, p. 119).

Depois dessa passagem, há um corte na narrativa, e deparamo-nos com Lázaro já ressuscitado, vivendo novamente em sua aldeia, na companhia de Jesus e de suas irmãs e amigos. Fica a impressão de que Rouah foi o responsável por sua ressurreição, e que o fez por meio da introdução da flor gigantesca e do cálice de carne em seu corpo. Algumas páginas à frente, 
encontramos o protagonista em sua casa, reunido com Jesus e os discípulos. Ao ouvir Cristo dizer que haverá um momento em que não estará mais entre eles, Lázaro sai da casa, angustiado: "Estou debaixo desse céu absurdo, arrasto-me, caminho de joelhos, beijo a terra, a terra escura e profunda. Apóio-me na figueira, tateio as artérias grossas desse tronco, essa aspereza, essa vida digna, esse existir calado" (Hilst, 2003, p. 129-130). Uma vez mais podemos construir um diálogo com a oposição que guia nossa leitura. Primeiro, o personagem menciona o "céu absurdo", que remete à ideia de infinitude, de uma vastidão sufocante. Em seguida, à angústia causada pelo confrontamento com a vastidão junta-se a angústia diante do silêncio do mundo, representado pelo "existir calado" da figueira, que remete à ideia de falta. Mesmo depois de ressuscitado, o Lázaro de Hilst continua a experienciar o estranhamento que, conforme Heidegger, é condição para o desentranhar do ser para a morte.

Enquanto submerge em tais impressões angustiantes, o personagem se depara com novo acontecimento insólito: ele percebe três homens correndo em sua direção. Estes, ao alcançá-lo, cobrem sua cabeça e começam a espancá-lo: “És Lázaro, não és? És Lázaro, o imundo, o mentiroso, não és? Pois toma, canalha, toma, para não ludibriares os humildes. E recebo golpes na cabeça, no ventre, no peito. Acordo com o ruído do mar. Água nos pés" (Hilst, 2003, p. 131). Conforme o excerto, o personagem acaba por desmaiar durante o ataque e, quando acorda, encontra-se à deriva, no mar - e aqui há, novamente, o confrontamento com uma vastidão opressora -, num barco sem remos ou vela: "Abro os olhos. Estou sozinho num barco. Um barco sem vela, sem leme, sem remos" (Hilst, 2003, p. 131). Ele pergunta a si mesmo: "Há quanto tempo estarei sozinho neste barco, no mar?", e em seguida responde: "Ontem. Foi ontem, tenho certeza, porque era noite e agora é dia, o sol me fere os olhos, tenho feridas no corpo, ainda sinto aquelas mãos pesadas golpeando-me" (Hilst, 2003, p. 131). Esta certeza inicial, todavia, é logo substituída por uma dúvida improvável: "Foi ontem? Mas pode ter sido há dez dias, há cem dias, há mil anos. Não, isso é absurdo. É absurdo, Lázaro? Não é tudo tão absurdo?" (Hilst, 2003, p. 132). É de fato absurdo pensar que o personagem poderia estar à deriva há mil anos. Mas desse questionamento surge uma consciência pungente: "Não é tudo tão absurdo?". O desconserto causado por tais palavras prepara a cena narrada na sequência:

Não é absurdo ser o que sou? Quem és? Um morto-vivo, um mortovivo que sentiu a múltipla face do filho de Deus. Um morto-vivo a 
quem colocaram num barco sem vela, sem leme, sem remo, um morto-vivo que está vendo agora uma coisa: uma cidade! Aquilo é uma cidade! Casas tão altas como nunca vi. E o ruído que ouço é o ruído de um enorme pássaro sobre a minha cabeça. Senhor, eu morri e devo estar entrando no paraíso (Hilst, 2003, p. 132).

Como se para evidenciar a consciência dolorosa de que tudo é de fato absurdo, de que o mundo é de fato mudo, fechado num silêncio inescrutável, numa falta impreenchível e angustiante, numa recusa ríspida de explicações, Lázaro acorda em um barco sem remos, mil anos mais tarde, ou até mais: o personagem descreve casas tão altas como nunca viu, e um pássaro enorme e ruidoso que passa sobre sua cabeça. Apesar de não haver referências explícitas, fica a impressão de que tais casas exageradamente altas são prédios, e de que o pássaro enorme e ruidoso é um avião.

Sem que se explique por que meios, ele é acolhido por um grupo de religiosos, liderados por certo Frei Benevuto, numa espécie de mosteiro. Ali, ele se depara com uma série de imagens do Cristo Crucificado pelas paredes: "No centro da parede há outro homem crucificado. Pergunto novamente quem é. O velho monge, o único que me entende, diz que é o homem Jesus, que o homem Jesus está em todas as paredes desta casa" (Hilst, 2003, p. 133). Frei Benevuto - "o único que entende" o protagonista, possivelmente, por dominar sua língua nativa (aramaico) devido a seus estudos teológicos - explica então a Lázaro que Jesus morreu crucificado há muito tempo, pela remissão dos pecados da humanidade. Diante de tais palavras, o protagonista se revolta:

Mestre, ajuda-me, eu não vim até aqui para não ser entendido, eu não vim até aqui para saber que te crucificaram há muito tempo atrás e que eu fui impotente diante da Tua morte, não é verdade essa coroa de espinhos, essa cruz, e Tu não tinhas esse rosto, tinhas um rosto impossível de ser imitado pela mão do homem, e depois eu Te deixei ainda ontem, agora estou certo de que foi ontem, tenho a mesma roupa no corpo, o velho monge me disse que alguém quis brincar comigo colocando-me esta roupa, mas eu sei que esta roupa foi feita por Marta, e que o sangue nesta túnica é o sangue dos meus joelhos, eu sei quem sou, eu sou Lázaro, e se a Tua morte fosse verdade, Mestre, se tivesse morrido na cruz, como dizem, o rosto dos homens não seria mais o mesmo rosto, não teria sentido que fosse o mesmo rosto, o rosto dos homens seria uma chama, seria luz, seria igual ao Teu rosto (Hilst, 2003, p. 135). 
A indignação de Lázaro decorre daquilo que Dastur chama de "o paradoxo do crucificado": "É com o cristianismo que aparece a idéia de um Deus triunfando sobre a morte, e é com ele também que é ressaltado o trágico da condição humana, sob a forma da morte na cruz de um Cristo abandonado por um Deus que silencia" (Dastur, 2002, p. 24). Aos olhos do velho monge, todavia, as palavras do protagonista são desvarios proferidos por um lunático que pensa ter vivido à época e em companhia de Cristo. Para Lázaro se acalmar, ele explica que não há motivo para desespero, pois, depois de ter sido crucificado e morrido, Jesus ressuscitou e foi para os céus. A reação do personagem, todavia, não é a esperada: “O quê? Ele está no céu? Mas isso não é verdade, o Homem Jesus não ressuscitaria para ficar no céu e esquecer-se dos homens" (Hilst, 2003, p. 136). E em seguida: "Não, não, velho monge, não é do seu feitio subir ao céu, Ele gosta de estar entre os homens, gosta de se aquecer em nossa casa, preocupa-se com a nossa vida" (Hilst, 2003, p. 136). Talvez por impacientar-se, ou por perceber que não conseguirá diminuir a angústia de seu visitante, Frei Benevuto muda o tom de seu discurso:

Escuta, filhinho, Lázaro, meu filhinho, o Jesus de quem falas está morto há muito tempo, e para os homens de agora nunca ressuscitou, nem está em lugar algum nem... não te aborreças, mas... sabemos que Ele... que Ele nunca existiu, Ele foi apenas uma idéia, muito louvável até, mas... Ele foi apenas uma tentativa de... bem, se tudo corresse bem, essa idéia que inventaram, essa imagem, poderia crescer de tal forma que aplacaria definitivamente a fera dentro do homem. Mas não deu certo. Pelo contrário. Os homens não se comoviam com Jesus, viviam repetindo que muitos sofreram mais do que Ele, que Ele ainda era feliz, era feliz porque acreditava que era filho de Deus, e os homens que nascem e morrem a cada dia sabem que são filhos do homem com a mulher e não têm consolo algum, lutam para dar alimento, roupa, e alguma alegria aos seus filhos e a si próprios. Lutam sempre. Vivem e morrem. É o que acontece aos humanos. Não há nada além disso (Hilst, 2003, p. 137).

Esta é, talvez, a mais pungente das experiências insólitas vividas por Lázaro, e a passagem que melhor evidencia o quanto o personagem encarna o conceito de ser para a morte. Se observamos, no início de nossas reflexões, que o episódio bíblico da ressurreição de Lázaro 
representa a vitória sobre a morte, de forma ainda mais contundente o representa a ressurreição de Cristo. A afirmação de que Jesus sequer existiu, contraditoriamente proferida pelos lábios de um religioso, constitui a negação de qualquer possibilidade de superação da morte. Configura-se aí a afirmação do ser finito, do enfrentamento e da consciência da morte. Nas linhas finais do excerto, lemos que "os homens que nascem e morrem a cada dia sabem que são filhos do homem com a mulher", e que "não há nada além disso". Mais do que negar a existência de Cristo, portanto, trata-se de negar a própria existência de Deus. De transformar a idéia máxima da representação da infinitude na falta mais lancinante e irrevogável. A ausência de Deus vivenciada por Lázaro ao final de sua jornada absurda torna-se, assim, a mais extrema representação da falta, do vazio, do silêncio, e a angústia que brota desse enfrentamento desentranha o ser para a morte.

Ao final do texto, temos um corte brusco na narrativa, marcado por um espaço em branco. Abaixo desse espaço, encontramos apenas três linhas, e Lázaro já não é mais o narrador: "Lázaro grita. Um grito avassalador. Um rugido. Arregala os olhos e vê Marta. Ela está de pé, junto à cama. As duas mãos sobre a boca" (Hilst, 2003, p. 141). A imagem de Marta com as mãos sobre a boca remete ao início do texto, quando Lázaro relatava de que forma se dera sua morte, e sugere que ele talvez tenha apenas adormecido e tido um sonho absurdo; ou até que tenha de fato morrido, vivenciado todas as experiências que são relatadas ao longo da narrativa, e então voltado à vida, em sua própria casa. De qualquer maneira, o sentido fica suspenso, e mesmo que se adote uma das duas leituras apresentadas, acreditamos que estas não invalidam as reflexões propostas ao longo de nosso artigo.

Nestas breves páginas, portanto, procuramos fazer dialogarem a narrativa "Lázaro", de Hilda Hilst, e o conceito de ser para a morte, de Martin Heidegger. Tal conceito, como vimos, representa a possibilidade mais própria e irremissível que o Dasein pode assumir, à medida que instaura a consciência do saber-se finito, e é no seio da angústia que ela se desentranha. Para compreender de que forma a angústia se manifesta no texto estudado, recorremos às reflexões de Burke, para quem ela irá se configurar ora em face de um falta primordial, ora em face de uma vastidão opressora. Como vimos, o narrador-protagonista de "Lázaro" depara-se constantemente com representações dessa falta e dessa 
vastidão e, por conta de tais enfrentamentos, vivencia o aflorar da angústia.

O fato de o conceito de angústia possuir profunda relação com o nada já seria, de certa forma, suficiente para estabelecer uma relação com a morte: angustiar-se, grosso modo, é angustiar-se diante da morte. Mas no caso específico de "Lázaro", esse entrelaçamento é realçado pela amputação de qualquer possibilidade de distanciamento da morte, primeiro por meio da subversão da imagem do Espírito Santo constituída na figura de um Rouah asqueroso, e depois, pela negação da ressurreição e da existência de Cristo, culminando na negação da existência de Deus. Em ambas as situações, a possibilidade de superação da morte representada pela ideia de transcendência é vetada, e a consciência demonstrada por Lázaro a respeito dessa impossibilidade faz dele uma encarnação do ser para a morte.

\section{Referências}

BURKE, Edmund (1993). Uma investigação filosófica sobre a origem de nossas idéias do sublime e do belo. Tradução, apresentação e notas de Enid Abreu Dobránzky. Campinas: Papirus.

DASTUR, Françoise (2002). A morte: ensaio sobre a finitude. Tradução de Maria Tereza Pontes. Rio de Janeiro: Difel.

Evangelho Segundo São João (2012). In: Bíblia de Jerusalém. São Paulo: Paulus, p. 1.842-1.895.

HEIDEGGER, Martin (1979). Que é metafísica? In: HEIDEGGER, Martin. Conferências e escritos filosóficos. Tradução e notas de Ernildo Stein. São Paulo: Abril Cultural, p. 25-51.

HEIDEGGER, Martin (2012). Ser e tempo. Edição em alemão e português. Tradução, organização, nota prévia, anexos e notas de Fausto Castilho. Campinas: Editora da Unicamp. Petrópolis: Vozes.

HILST, Hilda (2003). Lázaro. In: HILST, Hilda. Fluxo-Floema. São Paulo: Globo, p. 107-141.

KIERKEGAARD, Sören Aabye (2007). O conceito de angústia. Tradução de Eduardo Nunes Fonseca e Torrieri Guimarães. São Paulo: Hemus.

PERNIOLA, Mario (2000). Pensando o ritual: sexualidade, morte, mundo. Tradução de Maria do Rosário Toschi. São Paulo: Studio Nobel. 
POOLE, Roger (2009). The unknown Kierkegaard: Twentieth-century receptions. In: HANNAY, Alastair; MARINO, Gordon D. (Org.). The Cambridge Companion to Kierkegaard. New York: Cambridge University Press, p. 48-75.

ROSSET, Clément (2000). L'angoisse. In: ROSSET, Clément. Le monde et ses remèdes. 2. ed. Paris: Presses Universitaires de France, p. 43-81.

SELIGMANN-SILVA, Márcio (2005). Do delicioso horror sublime ao abjeto e à escritura do corpo. In: SELIGMANN-SILVA, Márcio. O local da diferença: ensaios sobre memória, arte, literatura e tradução. São Paulo: Editora 34, p. 31-44.

Recebido em março de 2015.

Aprovado em agosto de 2015.

\section{resumo/abstract/resumen}

\section{A angústia diante da morte em "Lázaro", de Hilda Hilst}

Willian André

Este artigo tem por objetivo construir uma reflexão sobre o tema da "angústia diante da morte" a partir da análise da narrativa "Lázaro" (1970), da escritora brasileira Hilda Hilst. Propondo uma releitura do episódio bíblico que narra a morte e ressurreição de Lázaro, o texto em questão permite-nos estabelecer um diálogo com o conceito de ser para a morte, de Martin Heidegger, bem como com a teoria do sublime de Edmund Burke, em cujo cerne se encontra a manifestação da morte. Ao traçar tais diálogos, pretendemos observar como o narrador-protagonista do texto de Hilst pode ser pensado como uma encarnação do ser para a morte heideggeriano.

Palavras-chave: ser para a morte, angústia, “Lázaro”, Hilda Hilst.

\section{Anguish in face of death: an analysis of "Lázaro", by Hilda Hilst}

Willian André

This article aims at building a reflection on the subject "anguish in face of death", based on the analysis of the narrative "Lázaro" (1970), by Hilda Hilst. Proposing a rereading of the biblical episode of Lazarus' death and resurrection, such text allows us to establish a dialogue with the concept of being-toward-death, by Martin Heidegger, as well as with Edmund Burke's theory of sublime, whose core is the manifestation of death. By drawing these dialogues, we expect to point out how the protagonist narrator of Hilst's text can be thought as an incarnation of Heidegger's being-toward-death.

Keywords: being-toward-death, anguish, "Lázaro”, Hilda Hilst. 


\section{La angustia ante la morte en "Lázaro", de Hilda Hilst}

Willian André

Este artículo tiene como objetivo construir una reflexión sobre el tema de "la angustia ante la muerte" a partir del análisis de la narrativa "Lázaro" (1970), de la escritora brasileña Hilda Hilst. Al proponer una nueva lectura del episodio bíblico que narra la muerte y resurrección de Lázaro, el texto en cuestión nos permite establecer un diálogo con el concepto de ser para la muerte, de Martin Heidegger, así como con la teoría de lo sublime, de Edmund Burke, en cuyo núcleo se encuentra la manifestación de la muerte. Al delinear dichos diálogos, tenemos la intención de observar cómo el narrador-protagonista del texto de Hilst puede ser pensado como una encarnación del ser para la muerte heideggeriano.

Palabras clave: ser para la muerte, angustia, "Lázaro", Hilda Hilst. 